\title{
Curcumin-cyclodextrin complexes potentiate gemcitabine effects in an orthotopic mouse model of lung cancer
}

\author{
N Rocks', S Bekaert', I Coia' ${ }^{2}$, G Paulissen', M Gueders', B Evrard², J-C Van Heugen ${ }^{3}$, P Chiap ${ }^{3}$, J-M Foidart', \\ A Noel' and D Cataldo*,I
}

'Laboratory of Tumor and Development Biology, GIGA-Research (Groupe Interdisciplinaire de Génoprotéomique Appliquée) - GIGA-Cancer and GIGA-13', University of Liege and CHU of Liege, Sart-Tilman, 4000 Liege, Belgium; ' Laboratory of Pharmaceutical Technology, University of Liege and CHU of Liege, Sart-Tilman, 4000 Liege, Belgium; ${ }^{3}$ Department of Analytical Pharmaceutical Chemistry, Institute of Pharmacy, University of Liege and CHU of Liege, Sart-Tilman, 4000 Liege, Belgium

BACKGROUND: Overall clinical outcome for advanced lung cancer remains very disappointing despite recent advances in treatment. Curcumin has been reported as potentially active against cancer.

METHODS: Owing to poor curcumin solubility, we have used cyclodextrins (CD) as an excipient allowing a considerable increase of aqueous solubility and bioavailability of curcumin. The effects of solubilised curcumin have been evaluated in cell cultures as well as in an in vivo orthotopic lung tumour mouse model.

RESULTS: Cell proliferation was reduced while apoptosis rates were increased when lung epithelial tumour cells were cultured in the presence of curcumin-CD complexes. For in vivo experiments, cells were grafted into lungs of C57B//6 mice treated by an oral administration of a non-soluble form of curcumin, CDs alone or curcumin-CD complexes, combined or not with gemcitabine. The size of orthotopically implanted lung tumours was reduced upon curcumin complex administration as compared with treatments with placebo or non-solubilised curcumin. Moreover, curcumin potentiated the gemcitabine-mediated antitumour effects.

CONCLUSION: Our data demonstrate that curcumin, when given orally in a CD-solubilised form, reduces lung tumour size in vivo. In vitro experiments show impaired tumour cell proliferation and increased cell apoptosis. Moreover, our data underline a potential additive effect of curcumin with gemcitabine thus providing an efficient therapeutic option for antilung cancer therapy.

British Journal of Cancer (2012) 107, 1083-1092. doi:I0.1038/bjc.2012.379 www.bjcancer.com

Published online 28 August 2012

(C) 2012 Cancer Research UK

Keywords: curcumin; cyclodextrin; lung cancer; gemcitabine; cell cycle

Lung cancer is an aggressive and progressive deadly disease with few treatment options and poor overall survival in non-surgical stages. Despite recent advances in the treatments for other cancer types, 5-year combined survival rates of patients bearing lung cancer of all stages is still only 16\% (American Cancer Society, 2010). Gemcitabine is widely used as a chemotherapeutic agent and has been approved by the FDA to be administered in combination with cisplatin in first- or second-line treatments of patients with locally advanced or metastatic non-small-cell lung cancers. However, the overall response to existing treatments is very often limited and several side effects, such as fatal pulmonary toxicity, have been described for treatment regimens including gemcitabine (Binder et al, 2011; Nasrallah et al, 2012).

Some nutraceuticals derived from fruits, vegetables or spices have demonstrated to have extra health benefits. One of those agents that could have a future as a new drug for anticancer treatment is curcumin (diferuloylmethane). Curcumin, a yellow-coloured polyphenol, is the main curcuminoid of the Indian spice turmeric (Curcuma longa), and some analogues such as demethoxycurcumin, bisdemethoxycurcumin as well as cyclocurcumin have also been described. While this natural agent has been widely used as a spice in Indian cuisine or in ayurvedic medicine in South-East

*Correspondence: Dr D Cataldo; E-mail: didier.cataldo@ulg.ac.be Revised 20 July 2012; accepted 26 July 2012; published online 28 August 2012
Asiatic countries, extensive research has been conducted within the last years and has reported anti-angiogenic, anticancer and antimetastatic effects for curcumin and derived molecules in in vivo animal models (Chen et al, 2008; Kunnumakkara et al, 2008; Shankar et al, 2008; Ravindran et al, 2009). Moreover, curcumin has recently been found to inhibit cancer cell proliferation and to induce apoptosis of cancer cells in vitro (Yodkeeree et al, 2009; Saha et al, 2010; Yadav et al, 2010). Notably, curcumin-based treatments have not shown any significant toxic side effects.

However, natural curcumin is unstable in the gastrointestinal tract and insoluble in water leading to a very poor bioavailability. Therefore clinical studies to eventually observe beneficial effects require administering very high doses of curcumin (Kanai et al, 2011). To overcome this extremely poor aqueous solubility, we have developed curcumin-cyclodextrin (CD) complexes that remarkably enhance curcumin solubility. Cyclodextrins are cyclic glucose polymers that bind hydrophobic molecules and form stable hydrophilic complexes with chemicals, enhancing thereby their water solubility (Evrard et al, 2004). The purpose of the present study was to evaluate the in vitro and in vivo effects of a soluble form of curcumin and to investigate the molecular mechanisms of lung cancer cell sensitisation to gemcitabine upon curcumin exposure. Our results demonstrate that mice treated with gemcitabine and curcumin-CD complexes display a reduction in size of orthotopically implanted lung tumours. We also provide 
in vitro evidence that $\mathrm{CD}$-curcumin complexes reduce cell proliferation rates and increase apoptosis rates, through a regulation of cell cycle protein production.

\section{MATERIALS AND METHODS}

\section{Materials}

Curcumin (93\% purity) was purchased from Sigma-Aldrich (St Louis, MO, USA). Hydroxypropyl- $\gamma$-CD (HP $\gamma$-CD or Cavasol W8 HP) (DS: 0.6) was obtained from Wacker-Chemie GmbH (Munich, Germany). Citric acid and acetonitril were of analytical grade.

\section{Formulation of curcumin-HP $\gamma$-CD inclusion complexes or curcumin suspension solution}

Hydroxypropyl- $\gamma$-CD was dissolved in a $\mathrm{pH} 7$ isotonic sodium citrate solution to obtain a concentration of $50 \mathrm{~mm}$. Curcumin $\mathrm{HP} \gamma$-CD inclusion complexes were prepared by adding an excess of curcumin into the $\mathrm{HP} \gamma$-CD solution. The mixture, stirred overnight at ambient temperature to form water-soluble inclusion complexes, was filtered through a $0.22-\mu \mathrm{m}$ filter to remove curcumin excess and sterilise the solution. Filtrate aliquots of curcumin solutions were quantified by a validated HPLC method and diluted to reach $1 \mathrm{~mm}$ of curcumin (Evrard et al, 2004). The curcumin suspension was prepared by adding curcumin in aseptic conditions into a sterile isotonic sodium citrate solution.

Solutions used for cell culture were made of $\mathrm{HP} \gamma-\mathrm{CD}(2.5 \mathrm{~mm}$ or $5 \mathrm{~mm}$ ) or curcumin-CD complexes containing $50 \mu \mathrm{M}$ curcumin$2.5 \mathrm{~mm} \mathrm{HP} \gamma$-CD or curcumin $100 \mu \mathrm{m}-5 \mathrm{~mm} \mathrm{HP} \gamma$-CD. Solution used for in vivo injection was curcumin $1 \mathrm{~mm}-50 \mathrm{~mm} \mathrm{HP} \gamma-\mathrm{CD}$.

\section{Cell culture}

Murine Lewis Lung Carcinoma cells (LLC or LL/2-luc-M38 Bioware Cell Line) stably transfected with luciferase gene were purchased from Caliper Life Sciences, Inc. (Teralfene, Belgium). The BZR cells were obtained from American Type Culture Collection (Manassas, VA, USA). Lewis Lung Carcinoma and BZR cells were grown at $37^{\circ} \mathrm{C}$, in $5 \% \mathrm{CO}$, in Dulbecco's Modified Eagle Medium (Invitrogen Corp./Life Technologies, Gent, Belgium) supplemented with $10 \%$ fetal bovine serum and $2 \mathrm{mmoll}^{-1}$ L-glutamine, penicillin-streptomycin (100 IU ml $\left.{ }^{-1}-100 \mu \mathrm{g} \mathrm{ml}^{-1}\right)$ (Invitrogen Corp./Life Technologies). Medium used to culture LLC cells was enriched with neomycin $\left(\mathrm{G} 418,0.02 \mathrm{mg} \mathrm{ml}^{-1}\right.$; Life Technologies, Grand Island, NY, USA).

\section{Orthotopic implantation of lung tumour cells}

Male C57Bl/6 mice (Charles River, Wilmington, MA, USA) (6-8 weeks) were used for orthotopic LLC cell injection. A final volume of $100 \mu \mathrm{l}$ of serum-free medium containing $2 \times 10^{6}$ luciferaseexpressing LLC cells was instilled into the trachea of mice previously anaesthetised with a xylazine-ketamine mixture $(n=8$ mice per treatment group). Lung tumour growth was assessed regularly using the bioluminescence in vivo Imaging System IVIS 200 (Xenogen Corp., Alameda, CA, USA). Twelve minutes before acquiring in vivo images, animals were injected intraperitoneally (i.p.) with $100 \mu \mathrm{l}$ of D-luciferin potassium salt solution (Promega, Leiden, The Netherlands) diluted in PBS $\left(0.03 \mathrm{~g} \mathrm{ml}^{-1}\right)$ and anaesthetised in a plexiglas chamber using a mixture of $2.5 \%$ isoflurane/oxygen. A digital grayscale image of the animal placed in dorsal position was first acquired followed by the acquisition of a pseudocolour image representing the detected photons emerging from luciferase activity of LLC cells. Mice were imaged on days 7, $10,14,18$ and 21 after tracheal instillation of cells. Quantification of bioluminescence images was performed by determining 'regions of interest' (ROI) in the lung region of the animal and measuring bioluminescence intensity using Living Image software (Caliper Life Sciences, Inc.). At the end of the experiment, animals were killed and lung tissues were resected. A first half volume of the lung tissues was fixed in $4 \%$ paraformaldehyde and embedded in paraffin for histological analysis. The other half of lung tissues was snap-frozen in liquid nitrogen until used. Experiments were approved by the animal ethical committee of the University of Liege.

\section{Experimental protocol of treatment procedures}

Mice were randomised in five following experimental groups according to the given treatment ( $n=8$ mice per group): $\mathrm{HP} \gamma-\mathrm{CD}$, non-soluble curcumin, gemcitabine, curcumin-HP $\gamma$-CD or curcumin-HP $\gamma$-CD combined with gemcitabine. After intratracheal lung tumour cell instillation, animals were treated with either vehicle alone (HP $\gamma$-CD) (5 days per week, oral feeding with $93 \mathrm{mg} \mathrm{kg}^{-1}$ ), a non-soluble form of curcumin (NSC) (5 days per week, oral feeding with $3 \mathrm{mg} \mathrm{kg}^{-1}$ curcumin), gemcitabine (2 days per week, i.p. injection with $40 \mathrm{mg} \mathrm{kg}^{-1}$ ), curcumin-HP $\gamma$-CD complexes (5 days per week, oral feeding with $3 \mathrm{mg} \mathrm{kg}^{-1}$ curcumin) or curcumin-HP $\gamma$-CD complexes combined with gemcitabine injections (5 days per week, oral feeding with $3 \mathrm{mg} \mathrm{kg}^{-1}$ curcumin; 2 days per week, i.p. injection with $40 \mathrm{mg} \mathrm{kg}^{-1}$, respectively). Treatment of mice has been performed until killing of animals. Before instillation of tumour cells, mice were pretreated for 3 days with corresponding treatments.

\section{Mass spectrometry - extraction method}

Serum levels of curcumin or its metabolites have been analysed by LC-MS. For this, curcumin and tetrahydrocurcumin were extracted from mouse serum using ethyl acetate as described before (Zhongfa et al, 2012). The LC-MS/MS parameters were fixed as described by Zhongfa et al. Serum samples of curcumin-CD- or placebo-treated mice were analysed by the multiple reaction monitoring mode (Zhongfa et al, 2012).

\section{Immunohistochemistry}

Immunohistochemistry was performed on 5- $\mu$ m lung tissue sections. Sections were deparaffinised, and after unmasking antigens, treated with $3 \% \mathrm{H}_{2} \mathrm{O}_{2}$ in order to quench endogenous peroxidase activity. Blockade of nonspecific binding was performed by incubation with $\mathrm{PBS} /$ bovine serum albumin (Fraction V, Thermo Fisher Scientific, Geel, Belgium). Sections were incubated with a rat monoclonal antiKI67 (clone MIB-1, 1:100, Dako, Glostrup, Denmark). After several washes, slides were incubated with rabbit anti-rat biotin-coupled secondary antibody (Dako, 1:400) followed by incubation with streptavidin/horseradish peroxidase (HRP) complex (Dako, 1:500). Peroxidase activity was revealed using the $3-3^{\prime}$ diaminobenzidine hydrochloride kit (Dako). Slides were counterstained with haematoxylin and mounted.

Immunostainings were quantified using Image J program $(\mathrm{NIH}$, Bethesda, MA, USA). Briefly, image RGB colours were split and grey scale intensities corresponding to KI67 staining were measured in lung tumours. Results are expressed as the ratio between the surface of KI67-positive tumour area and the total surface of tumour tissue analysed. A minimum of eight slides per animal of each treatment group was examined and used for quantification.

Lung tumour size was determined on haematoxylin-eosin paraffin sections by measuring lung tumour area and reporting it to the total size of lung tissues using Image J software.

\section{Preparation of protein cell or tissue extracts}

Cells $\left(10^{6}\right)$ were seeded in $100-\mathrm{mm}$-diameter Petri dishes (Falcon, Becton Dickinson, Lincoln Park, NJ, USA) in serum-containing medium for $24 \mathrm{~h}$. Curcumin $(50 \mu \mathrm{M}$ or $100 \mu \mathrm{M})-\mathrm{CD}(2.5 \mathrm{~mm}$ or 
$5 \mathrm{~mm})$ complexes or vehicle alone $(5 \mathrm{~mm})$ were added to standard culture medium. After $24 \mathrm{~h}$ of culture, total protein cell extracts were prepared from cell monolayer by incubation for $15 \mathrm{~min}$ in radioimmune precipitation assay buffer ( $50 \mathrm{~mm}$ Tris- $\mathrm{HCl}, \mathrm{pH} 7.4 ; 150 \mathrm{~mm}$ $\mathrm{NaCl}$; $1 \%$ Nonidet P40; $1 \%$ Triton X-100; 1\% sodium deoxycholate; $0.1 \%$ SDS; $5 \mathrm{~mm}$ iodoacetamide; $2 \mathrm{~mm}$ phenylmethylsulphonyl fluoride). After centrifugation, supernatants were stored at $-20^{\circ} \mathrm{C}$. Total proteins were extracted from tumour tissues by incubating the crushed tissue with a lysis buffer ( $40 \mathrm{~mm}$ Tris, 20\% sucrose) containing 2\% SDS. Protein concentrations were determined using DC protein Assay kit (Bio-Rad Laboratories, Hercules, CA, USA).

\section{Proliferation assay}

Lewis Lung Carcinoma or BZR cells were seeded in sixplicate in 96well plates at a density of 1250 cells per well. After adhesion, cells were cultured in standard culture medium or treated with various concentrations of curcumin-CD complexes and/or gemcitabine (1-5-10 $\left.\mathrm{ng} \mathrm{ml}^{-1}\right)$ or with vehicle alone as control for 24 and $48 \mathrm{~h}$. Cell proliferation was evaluated by measuring 5-bromo- 2 -deoxyuridine incorporation during DNA synthesis, following the manufacturer's instructions (Roche Diagnostics $\mathrm{GmbH}$, Mannheim, Germany). Results are expressed as incorporation of $\mathrm{BrDU}$ measured by chemoluminescence (absorbance A450-A690nm).

\section{Cell cycle analysis}

Lewis Lung Carcinoma cells were cultured in standard culture medium supplemented with different concentrations of curcumin $(50 \mu \mathrm{m}$ or $100 \mu \mathrm{M})-\mathrm{CD}(2.5 \mathrm{~mm}$ or $5 \mathrm{~mm})$ complexes or with the vehicle alone ( $5 \mathrm{~mm}$ ) for $24 \mathrm{~h}$. The epithelial layer was dissociated as described before (Rocks et al, 2008a) and washed twice in PBS. Cell suspension was mixed in spermine tetrahydrochloride detergent as described by the manufacturer (BD Cycletest Plus DNA Reagent Kit; BD Biosciences, Erembodegem, Belgium). An equal volume of RNAse A and trypsine inhibitor was added to the samples and incubated at room temperature. Finally, cell suspensions were mixed to propidium iodide (PI), incubated at $4{ }^{\circ} \mathrm{C}$ and cell cycle phases were analysed on FACS Calibur (BD Biosciences).

\section{Flow cytometry}

Lewis Lung Carcinoma cells were cultured for $24 \mathrm{~h}$ in standard culture medium supplemented with different concentrations of curcumin $(50 \mu \mathrm{M}$ or $100 \mu \mathrm{M})-\mathrm{CD}(2.5 \mathrm{~mm}$ or $5 \mathrm{~mm})$ complexes or with the vehicle alone $(5 \mathrm{~mm})$. The epithelial layer was dissociated with PBS-EDTA (5 mM) and cells were detached by scraping (Rocks et al, 2008a). Lewis Lung Carcinoma cells were washed with PBS and then centrifuged and resuspended in $1 \times$ Binding Buffer (FITC Annexin V Apoptosis Detection Kit I, BD Biosciences). After incubation with FITC Annexin V and PI at room temperature, cells were analysed by flow cytometry using FACS Canto II (10000 events) (BD Biosciences).

\section{Western blot}

Samples (cell or tissue lysates) (20 $\mu$ g of total protein extracts) were separated under reducing conditions on polyacrylamide gels and transferred on PDVF membrane (NEN, Boston, MA, USA). After blocking in phosphate-buffered saline containing $10 \%$ non-fat milk and Tween $20(0.05 \%)$, membranes were incubated with the primary antibody: anti-poly (ADP-ribose) polymerase (PARP) rabbit monoclonal antibody, anti-cyclin B1 mouse monoclonal antibody, antiphospho-cyclin B1 rabbit polyclonal antibody and antiphospho-cdc2 (Thr161) rabbit polyclonal antibody (Cell Signaling, Leiden, The Netherlands). Immunoreactive proteins were visualised using the corresponding secondary antibody conjugated with HRP (DAKO) and the enhanced chemiluminescence detection kit (PerkinElmer Life Sciences, Boston, MA, USA). As loading control, actin levels were determined. Results are expressed as ratio between measured protein levels and corresponding actin levels.

\section{Statistical analysis}

Statistical differences were assessed between in vivo or in vitro experimental groups using Mann-Whitney test. ${ }^{*} P<0.05$, ${ }^{* *} P<0.01,{ }^{* * *} P<0.001$.

\section{RESULTS}

Curcumin-CD complexes display antitumour activity and potentiate the activity of gemcitabine in an orthotopic lung tumour mouse model

The effects of curcumin-CD complexes alone (curcumin-HP $\gamma-\mathrm{CD}$ ) or in combination with gemcitabine were examined on the growth of orthotopically implanted lung tumours in vivo. The experimental groups used herein included mice ( $n=8$ per group) treated with either (i) vehicle (HP $\gamma$-CD), or (ii) NSC (i.e., suspension of curcumin), or (iii) gemcitabine or (iv) curcumin complexed with $\mathrm{HP} \gamma-\mathrm{CD}$ (curcumin-HP $\gamma-\mathrm{CD}$ ), or (v) the association of curcumin$\mathrm{HP} \gamma$-CD with gemcitabine (curcumin-HP $\gamma$-CD + gemcitabine) (Figure 1A). After three consecutive days of pretreatment, LLC cells were orthotopically implanted into lung parenchyma and then corresponding treatments were continued during the whole experiment (for 5 days per week) (Figure 1A). Lung tumour development was monitored on days 7, 10, 14, 18 and 21 after tumour cell injection using IVIS imaging. Quantification of bioluminescence imaging pointed to a reduced lung tumour growth when mice were treated with gemcitabine or curcumin-CD complexes as compared with mice treated with vehicle alone or non-soluble curcumin $\left({ }^{*} P<0.05\right)$ (Figure $1 \mathrm{~B}$ right and left panels). Interestingly, lung tumour development was almost completely abolished when mice were treated by the association of curcumin$\mathrm{HP} \gamma$-CD and gemcitabine ${ }^{* * *} P<0.001 v s$ vehicle alone or nonsoluble curcumin). Tumour incidence rates were assessed in two individual experiments using bioluminescence imaging and showed that mice treated with gemcitabine and/or curcumin-CD complexes displayed lower tumour incidence rates than mice treated with vehicle alone or non-soluble curcumin (Figure 1C, day 7: ${ }^{\star} P<0.05$ or ${ }^{*}{ }^{*} P<0.01$ vs $\mathrm{HP} \gamma-\mathrm{CD}$; day $14:{ }^{\star} P<0.05$ or $* * P<0.01$ vs gemcitabine or curcumin-HP $\gamma$-CD or gemcitabinecurcumin-HP $\gamma-\mathrm{CD}$ ). Interestingly, on day 21 , tumour incidence rates were below $45 \%$ in the group of mice treated with combined curcumin-HP $\gamma-\mathrm{CD}$ and gemcitabine, intermediate $(60-70 \%)$ in mice treated with each chemotherapeutic alone, and reached $100 \%$ in groups treated with vehicle alone or non-soluble curcumin (Figure $1 \mathrm{C},{ }^{\Phi} P<0.01$ vs gemcitabine-curcumin-HP $\gamma-\mathrm{CD}$ or ${ }^{*} P P<0.01$ vs gemcitabine or curcumin-HP $\gamma$-CD or gemcitabinecurcumin-HP $\gamma$-CD).

The lung area occupied by tumour cells was quantified at day 21 on eight randomly selected haematoxylin-eosin sections per animal in each experimental group (Figure 1D). Lung tumour area/total lung area ratio was significantly lower in mice treated with curcumin-HP $\gamma$-CD-gemcitabine than in those of all other groups ( ${ }^{\Phi} P<0.001$ vs other groups). Moreover, groups treated with curcumin-HP $\gamma-\mathrm{CD}$ or gemcitabine displayed smaller tumour surfaces than groups treated with $\mathrm{HP} \gamma-\mathrm{CD}$ or NSC $\left({ }^{* * * P}<<0.001\right.$ vs curcumin-HP $\gamma-\mathrm{CD}$ or gemcitabine or curcumin-HP $\gamma-\mathrm{CD}-$ gemcitabine) (Figure 1E).

\section{Analysis of pooled serum samples by mass spectrometry} reveals the presence of tetrahydroxycurcumin

In order to investigate whether curcumin absorption is higher when it has been complexed to CDs and to understand its higher 

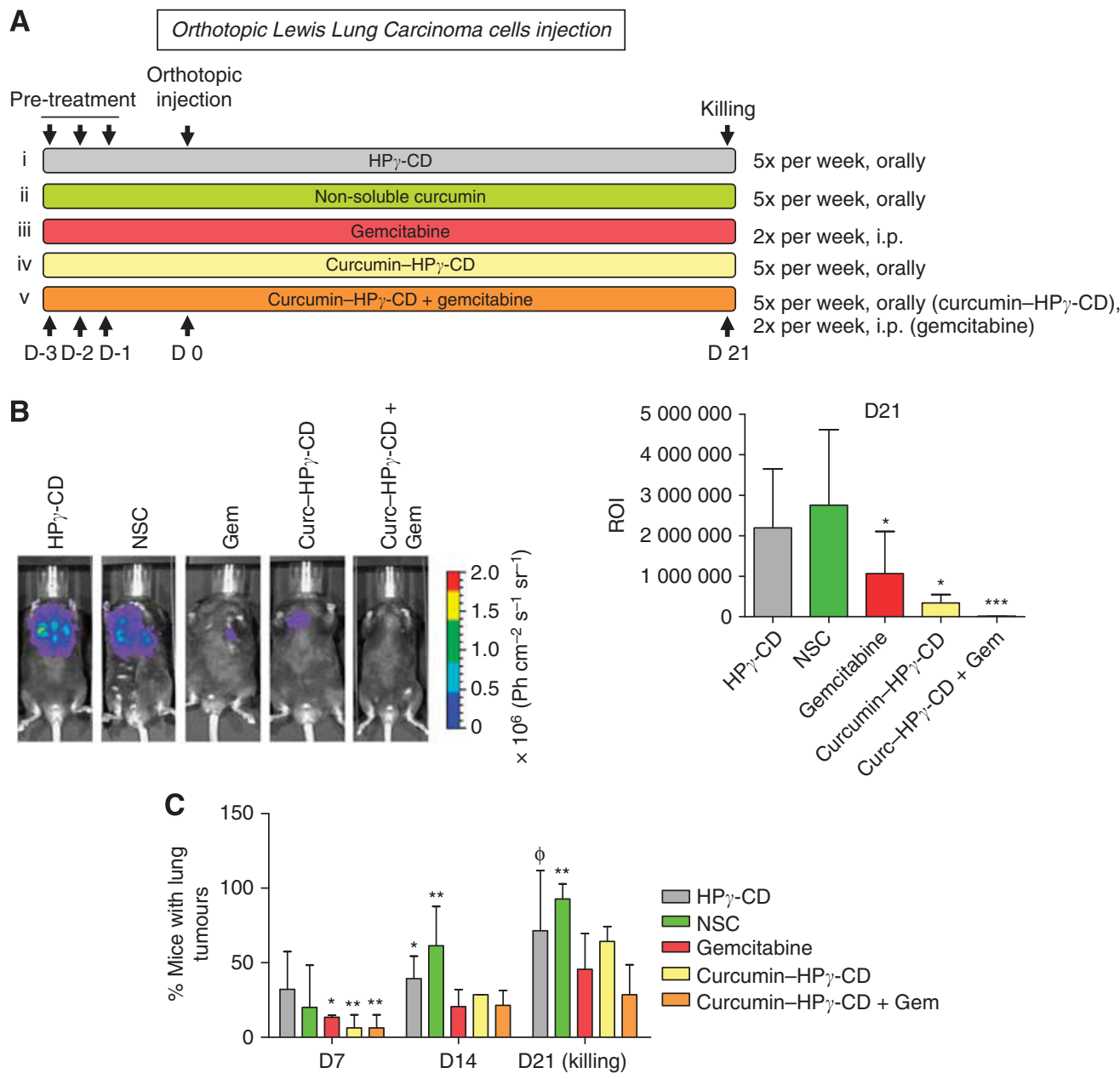

D

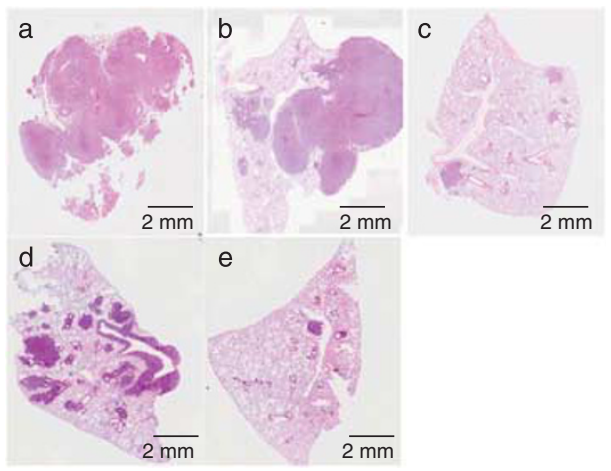

E

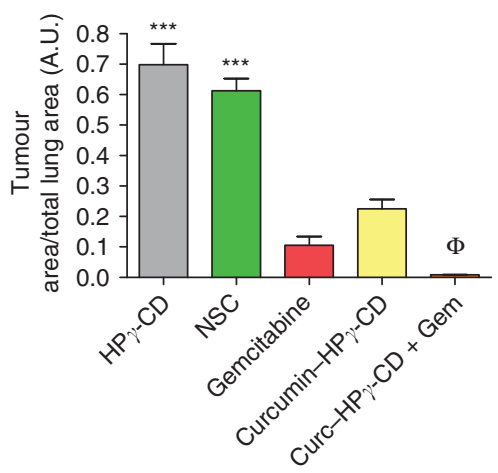

Figure I Curcumin-CD complexes potentiate the effects of gemcitabine and reduce growth of orthotopically implanted lung tumours in mice. (A) Experimental protocol used in this study. Hydroxypropyl- $\gamma-\mathrm{CD}\left(93 \mathrm{mg} \mathrm{kg}^{-1}\right)$, non-soluble curcumin (NSC; 3 mg kg ${ }^{-1}$ ), curcumin-CD complexes $\left(3 \mathrm{mg} \mathrm{kg}^{-1}\right)$ are given orally daily while gemcitabine is given twice per week $\left(40 \mathrm{mg} \mathrm{kg}^{-1}\right)$ i.p.. Treatment is started 3 days before orthotopic instillation of LLC cells (D0) and continued until killing. (B) Left panel: monitoring of lung tumour growth using Xenogen IVIS in animals (here: 2 I days after injection of LLC cells). Right panel: bioluminescence quantification of lung tumours on whole animals by determining ROI around lung area and measuring luciferase activity in lungs. $* P<0.05$, *** $P<0.00$ I vs HP $\gamma$-CD or non-soluble curcumin. (C) Incidence of lung tumours in mice. Incidence of lung tumours is reduced in

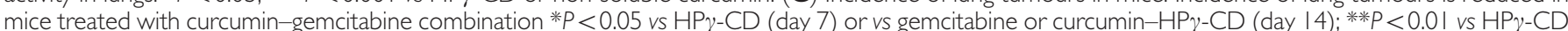

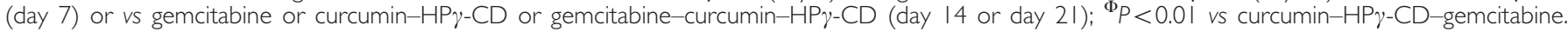
(D) Representative haematoxylin-eosin ( $\mathrm{H}-\mathrm{E}$ ) sections of lung tissues at autopsy. Magnification $\times 200$. (E) Tumour surfaces were assessed by measuring the ratio between the area of lung tumour and total lung tissue area on eight $\mathrm{H}$-E sections per mouse in each treatment group. Results are expressed as the mean lung tumour area/total lung area \pm s.e.m. (a.u.) and are representative of two experiments performed individually ( $n=8$ mice per treatment group).

efficiency against lung tumour development, we performed a mass spectrometry analysis on serum samples of animals treated with curcumin-CD or native curcumin. Mass spectrometry analysis revealed the presence of tetrahydroxycurcumin traces in serum of mice treated with curcumin-CD complexes, which are barely or not detectable in non-soluble curcumin-treated mice suggesting an enhanced biodisponibility of the complexed form of curcumin (Figure 2). Those results might explain the 


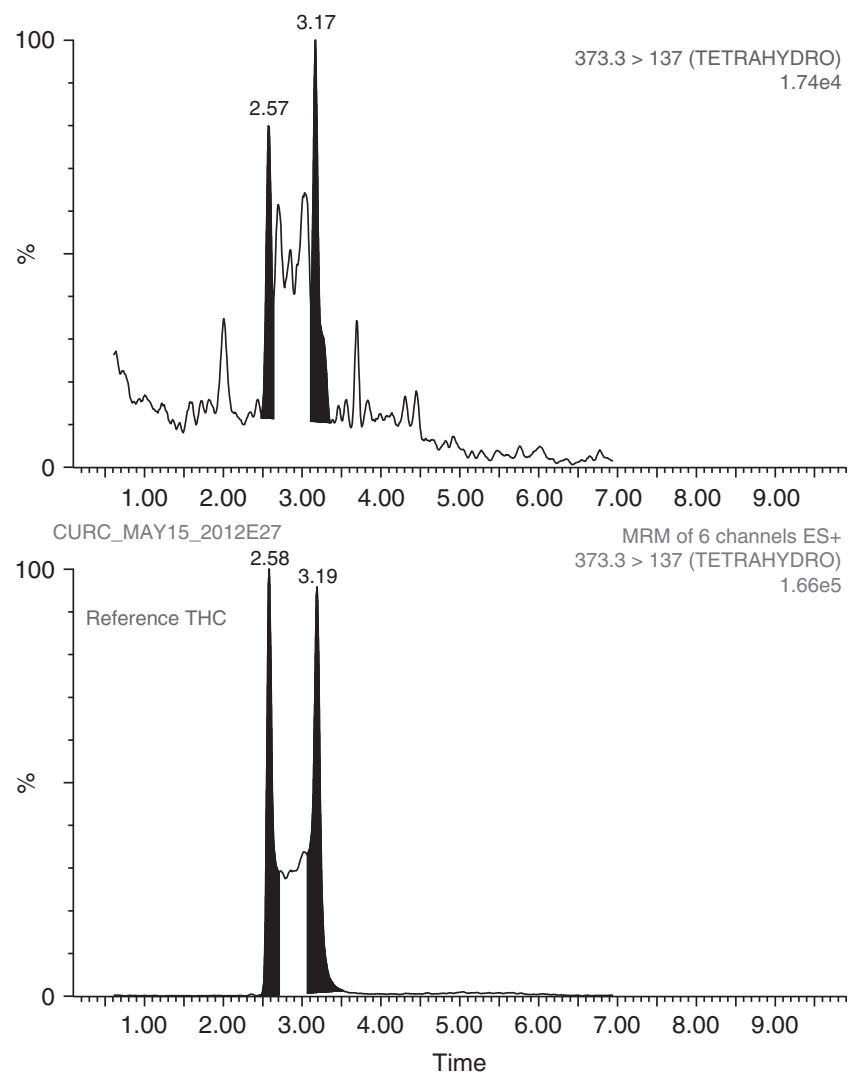

Figure 2 Representative mass spectrometry chromatograms of extracts of serum from mice that have been treated with curcumin-CD complexes. Tetrahydrocurcumin spectra measured in those sera have been compared with a spectrum emitted by native tetrahydroxycurcumin.

higher efficiency of curcumin against lung tumours in the present study.

\section{Cyclodextrin-complexed curcumin inhibits lung tumour cell proliferation in vitro as well as in vivo}

In order to further investigate the mechanisms underlying the antitumoral effects of curcumin-HP $\gamma$-CD complexes, we evaluated the proliferation index in lung tumours by KI67 immunostaining on lung tissue sections (Figure $3 \mathrm{~A}$ ). The association of curcumin$\mathrm{HP} \gamma-\mathrm{CD}$ and gemcitabine resulted in a two-fold reduction of proliferation index in mouse lung tumours as compared with lung tumours in mice treated by vehicle only or non-soluble curcumin $\left({ }^{*} P=0.027\right.$ vs vehicle; $P=0.0456$ vs non-soluble curcumin) (Figure $3 \mathrm{~B}$ ). No difference was observed between groups treated with curcumin- $\mathrm{HP} \gamma-\mathrm{CD}$ or gemcitabine alone and vehicle or nonsoluble curcumin groups $(P>0.05)$.

We next investigated the in vitro proliferation of LLC cells cultured in standard culture conditions or in the presence of different concentrations of curcumin $(10,20,50$ and $100 \mu \mathrm{M})$ complexed with $\mathrm{HP} \gamma$-CD or of $\mathrm{HP} \gamma$-CD alone $(0.5,1,2.5$ and $5 \mathrm{~mm})$. A dose-dependent reduction of tumour cell proliferation was observed after 24 and $48 \mathrm{~h}$ of treatment with curcumin-CD complexes, but not with $\mathrm{CD}$ alone $(\mathrm{HP} \gamma-\mathrm{CD}) \quad\left({ }^{*} P<0.01\right.$ vs corresponding control) (Figure $4 \mathrm{~A}$ and $\mathrm{B}$ ). Similar results have been obtained for BZR human lung epithelial tumour cells, where treatment with curcumin $(10,20$ and $50 \mu \mathrm{M})-\mathrm{CD}(0.5,1$ and $2.5 \mathrm{~mm})$ complexes during $48 \mathrm{~h}$ reduced cell proliferation in vitro (data not shown). Interestingly, in vitro proliferation of LLC and BZR cells exposed to the combination of curcumin-CD complexes and gemcitabine (5 or $10 \mathrm{ng} \mathrm{ml}^{-1}$ ) was significantly lower as compared with cell proliferation when exposed to corresponding concentrations of gemcitabine or curcumin-CD $\left({ }^{* *} P<0.001\right.$ vs corresponding concentration of gemcitabine or curcumin-CD alone) (Figure 4B).

\section{Cell cycle progression is arrested in G2-phase when cells are treated with curcumin-CD complexes}

As KI67 is a protein present in all active phases of the cell cycle, and in order to unveil which cell cycle phase is affected by curcumin treatment, we have analysed the distribution of cells in different phases of cell cycle in vitro using BD Cycletest Plus DNA Reagent Kit. Treatment of cells in the presence of curcumin-CD complexes significantly increased the proportion of cells in G2 phase when compared with treatment of cells with CDs alone or in standard culture medium (Figure $4 \mathrm{C}-\mathrm{G}$ and $\mathrm{H}$ ). The percentage of cells in S-phase was between $40-60 \%$ (Figure $4 \mathrm{H}$ ).

\section{Curcumin-CD complexes induce apoptosis of lung tumour cells in vitro}

Tumour development is dependent on alterations in regulatory circuits that govern normal cell proliferation and apoptosis. Genes implicated in cell cycle arrest have already been largely described to be associated to apoptosis induction in cells (Pawlik and Keyomarsi, 2004). In order to investigate the putative effects of curcumin combined to CDs on regulatory cellular circuits, early or late apoptosis rates were assessed in vitro by flow cytometry using FITC-conjugated annexin V and PI double staining (Figure 5A-E). Treatment of cells with curcumin-HP $\gamma-C D$ increased the percentage of annexin $\mathrm{V}$-positive LLC cells (referring to early apoptosis) from $0.5 \%$ (control) or $0.4 \%$ ( $\mathrm{HP} \gamma-\mathrm{CD}$ ) to $2.7 \%$ and $5.7 \%$ (for 50 and $100 \mu \mathrm{m}$ curcumin, respectively) (Figure 5A-D). Moreover, the number of cells positive for both stainings (referring to late apoptosis) reached $35 \%$ when cells were cultured in the presence of higher concentrations of curcumin $(100 \mu \mathrm{M})$ when compared with control $(1.2 \%)$ or vehicle alone (8.3\%) (Figure 5A, B and D). Interestingly, cell treatment with a combination of curcumin $(50 \mu \mathrm{M})-\mathrm{CD}(2.5 \mathrm{~mm})$ and gemcitabine increased the percentage of cells undergoing early apoptosis (10.4\%) as well as late apoptosis (68 vs 9.5\% when treated with curcumin $(50 \mu \mathrm{M})-\mathrm{HP} \gamma-\mathrm{CD}(2.5 \mathrm{~mm})$ alone) (Figure 5E).

Poly (ADP-ribose) polymerase is a nuclear polymerase involved in DNA repair in response to environmental stress. Cleavage of PARP is performed by ICE-like caspases and results in its inactivation leading to cellular disassembly. In the present study, cleaved PARP/total PARP ratios were significantly more important in cells cultured with curcumin-HP $\gamma$-CD $\left({ }^{*} P<0.05\right.$ vs $\mathrm{HP} \gamma$-CD $(2.5 \mathrm{~mm}) ;{ }^{* *} P<0.01$ vs $\mathrm{HP} \gamma-\mathrm{CD}(5 \mathrm{~mm})$ ) (Figure $\left.5 \mathrm{~F}\right)$. Interestingly, highest cleaved PARP/total PARP ratios were found when combining treatments with CD-complexed curcumin and gemcitabine $\left({ }^{\Phi}<0.01\right.$ vs $\mathrm{HP} \gamma$-CD $(2.5 \mathrm{~mm})$ or curcumin $(50 \mu \mathrm{M})-\mathrm{CD}$ $(2.5 \mathrm{~mm})$ ) (Figure 5F). Similar results were obtained for BZR human epithelial lung tumour cells. Indeed, culture of BZR cells with increasing concentrations of curcumin-HP $\gamma$-CD complexes increased cleaved PARP/total PARP ratios in a dose-dependent way (data not shown).

Expression of genes controlling cell cycle and apoptosis is modulated in mice treated with curcumin-HP $\gamma-\mathrm{CD}$ complexes and gemcitabine

In order to confirm in vitro results, PARP levels were measured in lung tissues of mice bearing tumours. Interestingly, highest levels of cleaved PARP protein and consequently highest tumour cells apoptosis rates were found in lung tissues of mice treated with a combination of gemcitabine and curcumin-HP $\gamma-\mathrm{CD}$ complexes $(P<0.01$ when compared with mice treated with 
A

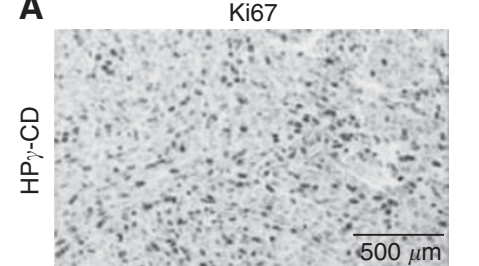

䛼
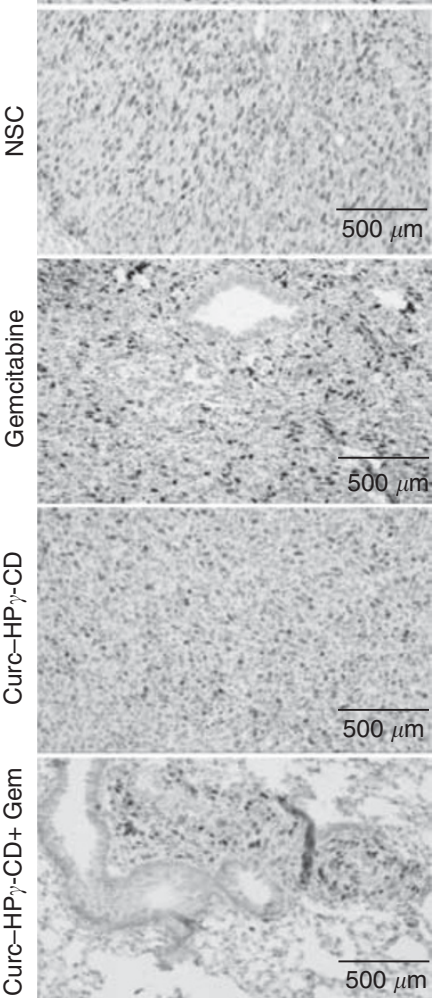

B

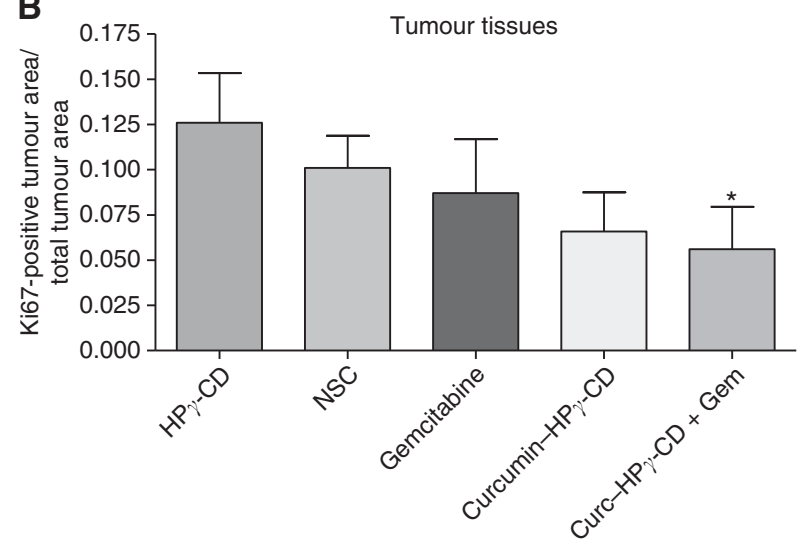

Figure 3 Curcumin-CD complexes inhibit lung tumour cell proliferation in vivo. (A) Immunohistochemical analysis of KI67 marker in lung tumours. Magnification $\times$ 400. (B) Quantification of KI67 staining in lung tumours. KI67-positive area in lung tumours is reported to total area of lung tumours. Results are expressed as mean \pm s.e.m. ( $P=0.027$ for HP $\gamma$-CD vs curcumin-HP $\gamma$-CD-gemcitabine; $P=0.0456$ for non-soluble curcumin vs curcumin-HP $\gamma$ CD-gemcitabine) ( $n=8$ mice per treatment group).

HP $\gamma$-CD, non-soluble curcumin or gemcitabine, $P<0.05$ when compared with mice treated with curcumin-CD complexes alone). Treatment with gemcitabine did not affect per se PARP cleavage in lung tissues when compared with control groups; while treatment of mice with curcumin-HP $\gamma$-CD complexes was a strong inducer of this cleavage (Figure 6A and $\mathrm{B}$ ).

As in vitro treatment of lung tumour cells with curcumin-CD is linked to a dysregulation of cell cycle and induced G2/M cell cycle arrest, we studied the relationship between apoptosis induction and the expression of genes implicated in G2/M transition of cell cycle in mouse lung tissues. Interestingly, we found higher levels of phosphorylated cdc2 (threonine 161) in lungs of mice treated with $\mathrm{HP} \gamma-\mathrm{CD}$ or non-soluble curcumin (NSC) $\left({ }^{*} P<0.05\right)$ when compared with mice treated with gemcitabine, curcumin or the combined treatment of curcumin-HP $\gamma-\mathrm{CD}$ and gemcitabine (Figure 6A and C). Levels of phospho-cyclin B1 were also higher in $\mathrm{HP} \gamma-\mathrm{CD}$ and NSC-treated groups although not significant (Figure 6A and D).

\section{DISCUSSION}

Lung cancer still remains a major public health problem and treatment schemes including newly discovered drugs often do not reach expected benefits (Binder et al, 2011; Nasrallah et al, 2012).
New treatment options combining high efficacy against lung tumour cells and low toxicity against normal pulmonary tissues are therefore urgently needed.

In this work, we tested the potency of curcumin-CD complexes to affect growth of lung tumours orthotopically implanted in mice. Moreover, complementary effects of curcumin-CD complexes to those of gemcitabine, a drug widely used to treat patients bearing lung or pancreatic cancer, were also investigated in in vivo as well as in vitro experimental settings.

The present study is the first report showing that curcumin-CD complexes display significant beneficial effects on growth of lung tumours orthotopically implanted in mice. Indeed, after 21 days, lung tumours were found in $100 \%$ of animals treated with vehicle alone or with the NSC but only in about $70 \%$ of animals treated with curcumin-CD complexes or with gemcitabine and in $<45 \%$ of animals treated with the association of curcumin-CD and gemcitabine. Moreover, lung tumour size was smaller in mice treated with the combination of curcumin-CD and gemcitabine as compared with all other treatment groups. These results are in accordance with the previous report of Kunnumakkara et al (2007) describing that curcumin potentiates the effects of gemcitabine in a murine pancreatic cancer model. It is worth noting that the results presented in our study also highlight the benefits of associating curcumin to CDs to form soluble complexes. Indeed, while most research groups were using doses reaching $1 \mathrm{~g} \mathrm{~kg}^{-1}$ or 
A
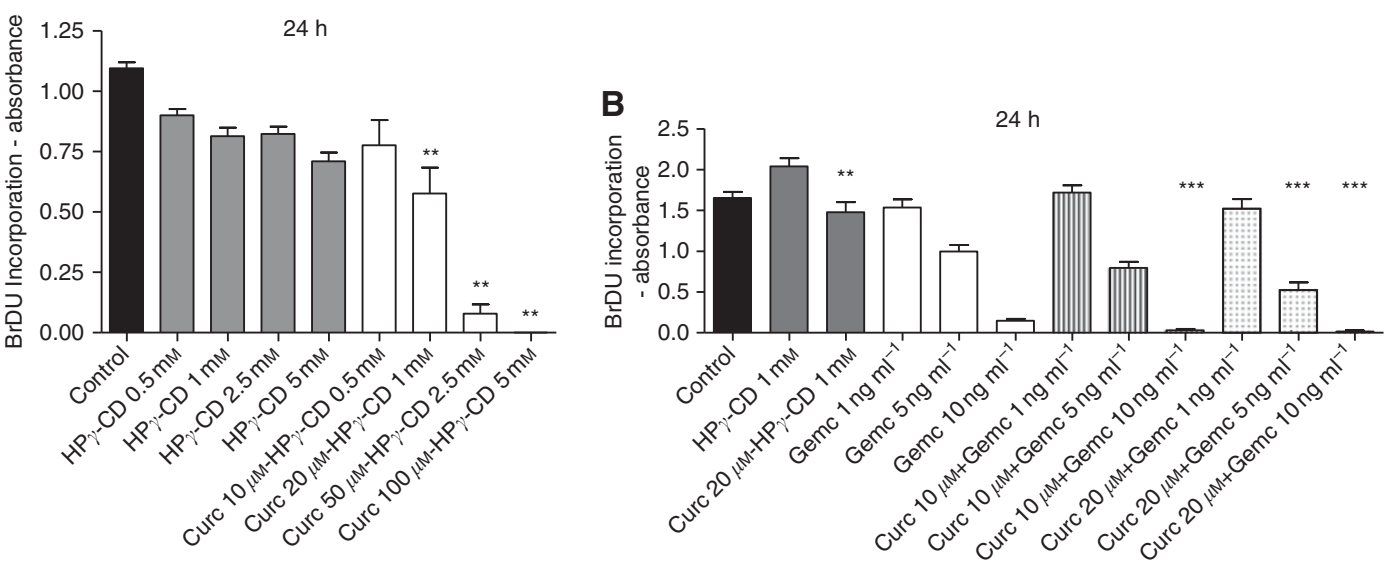

C

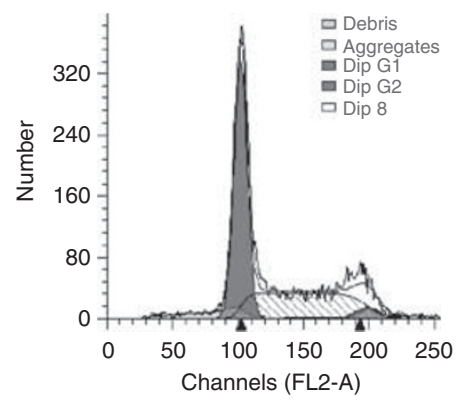

D

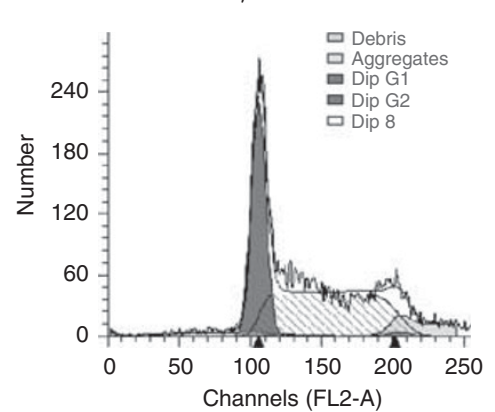

E

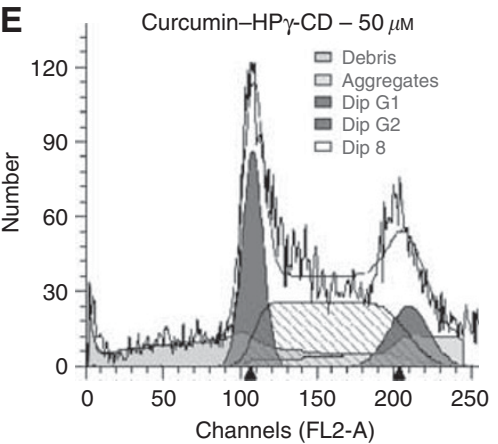

$\mathbf{F}$

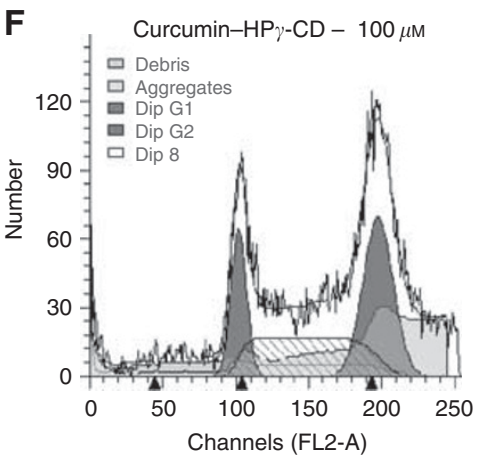

G

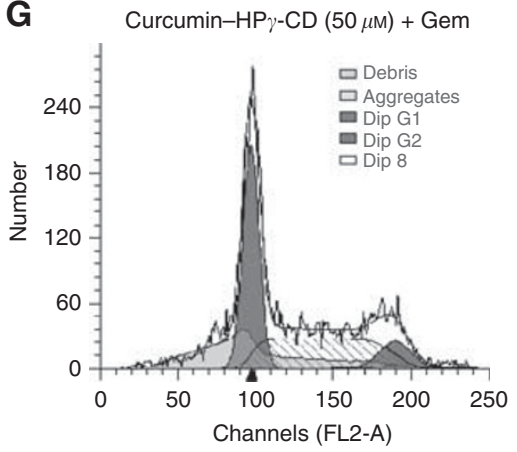

H

\begin{tabular}{|l|c|c|c|}
\hline & G1 phase (\%) & G2 phase (\%) & S phase (\%) \\
\hline Control & 55.05 & 4.72 & 40.23 \\
\hline $\begin{array}{l}\text { HP } \gamma \text {-CD } \\
(5 \mathrm{~mm})\end{array}$ & 50.63 & 5.21 & 44.16 \\
\hline $\begin{array}{l}\text { curc }(50 \mu \mathrm{M})- \\
\text { HP } \gamma-C D\end{array}$ & 26.22 & 10.87 & 62.92 \\
\hline $\begin{array}{l}\text { curc }(100 \mu \mathrm{M})- \\
\text { HP } \gamma-\mathrm{CD}\end{array}$ & 16.61 & 44.19 & 39.20 \\
\hline $\begin{array}{l}\text { curc }(50 \mu \mathrm{M})- \\
\mathrm{HP} \gamma-\mathrm{CD}+\mathrm{Gem}\end{array}$ & 46.23 & 11.16 & 42.61 \\
\hline
\end{tabular}

Figure 4 Curcumin-CD complexes affect lung tumour cell proliferation in vitro and induce cell cycle arrest in G2. (A) Cell proliferation assay (BrDU incorporation) showing a dose-dependent reduction of LLC cell proliferation when cells are cultured with increasing doses of curcumin-CD complexes $(P=0.0022$ for curcumin 20,50 and $100 \mu \mathrm{m}$ vs corresponding controls). These results are expressed as mean of sixplicates \pm s.e.m. and are representative of three independent experiments, where each experiment has been performed in sixplicates. (B) Cell proliferation assay (BrDU incorporation) showing a reduction of cell proliferation when LLC cells are cultured with curcumin-CD complexes and increasing doses of gemcitabine $(* * *<<0.0$ I vs HP $\gamma$-CD I mm; **** $P<0.00$ I vs corresponding controls). These results are expressed as mean of sixplicates \pm s.e.m. and are representative of two independent experiments, where each experiment has been performed in sixplicates. (C-G) Cells have been cultured with curcumin-CD alone or associated to gemcitabine for $24 \mathrm{~h}$, stained with PI and cell cycle has been analysed by flow cytometry. $(\mathbf{H})$ Table summarising percentages of cells present in GI or G2 phases of cell cycle according to different treatment options. Results are representative of two individual experiments.

$500 \mathrm{mg} \mathrm{kg}^{-1}$ of a non-soluble curcumin (Kunnumakkara et al, 2007; Lin et al, 2007), or $40 \mathrm{mg} \mathrm{kg}^{-1}$ or $25 \mathrm{mg} \mathrm{kg}^{-1}$ of curcuminliposome formulations (Wang et al, 2008; Sreekanth et al, 2011), doses of curcumin used in our study were significantly lower $\left(3 \mathrm{mg} \mathrm{kg}^{-1}\right)$. These results underline the importance of solubilising curcumin by forming complexes with CDs, therefore improving the bioavailability of curcumin. Indeed, levels of tetrahydroxycurcumin have been measured by mass spectrometry in sera of mice treated with curcumin-CD while those were not present in sera of mice treated with non-solubilised curcumin. As cytotoxicity of CDs previously evaluated in vitro and in vivo is poor when given orally or by inhalation (Evrard et al, 2004), their use to solubilise curcumin is not expected to cause respiratory or systemic side effects that would compromise the efficacy of curcumin or other drugs used to treat lung cancer patients. Moreover, healthy mice daily fed or inhaled with curcumin-CD complexes during 4 weeks did not show any signs of toxicity or inflammation in the lung, liver or renal tissues (data not shown). Indeed, the lung, liver and kidney histology as well as blood urea measurements were strictly normal. Pulmonary functions assessed by measuring bronchial hyperresponsiveness as well bronchoalveolar lavage counts also did not display any abnormalities.

Proliferation of lung tumour cells was reduced in cohorts of mice treated with a combined therapy of curcumin-CD (given 
A

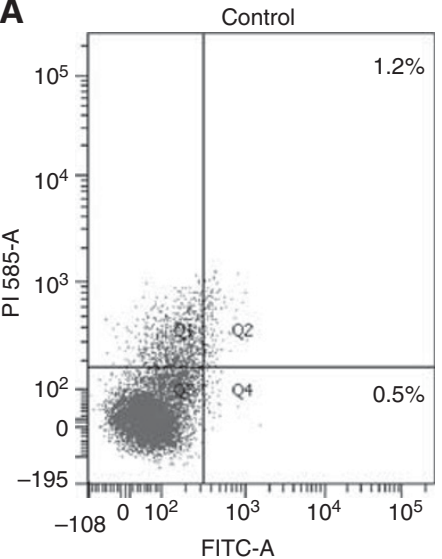

B

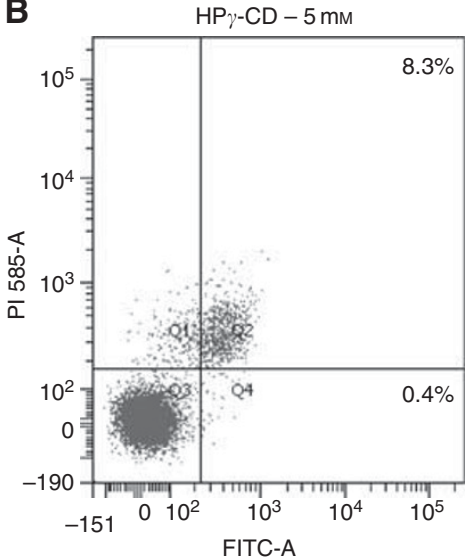

C

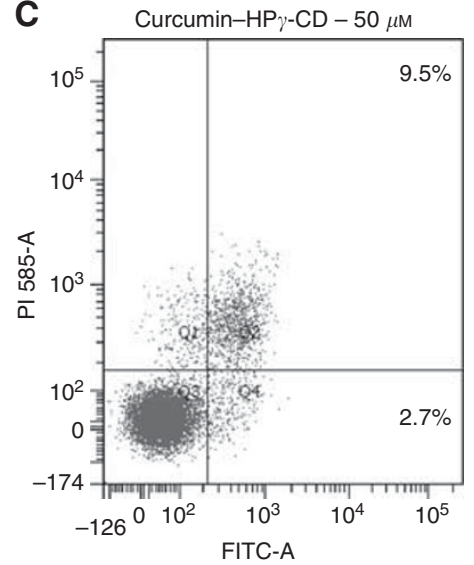

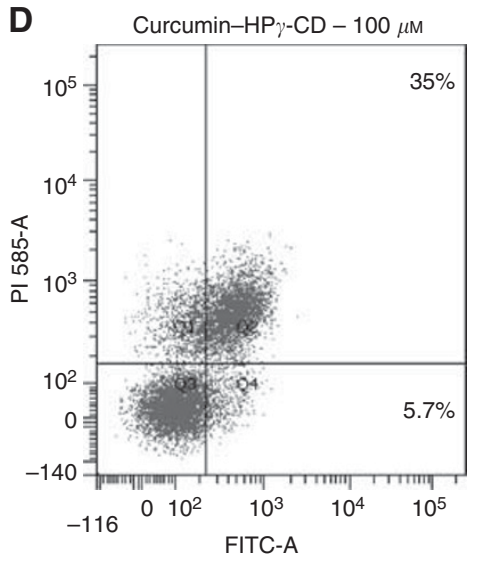

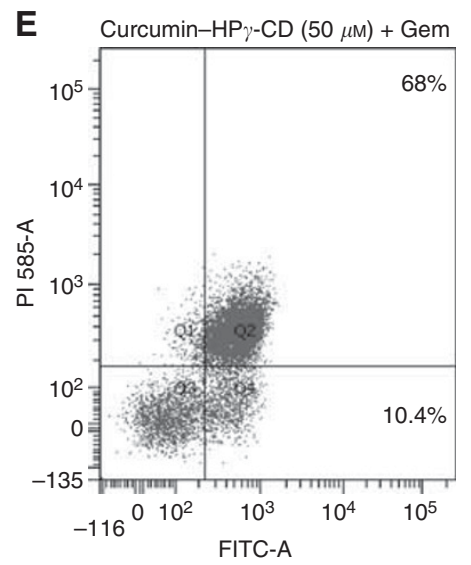

$\mathbf{F}$
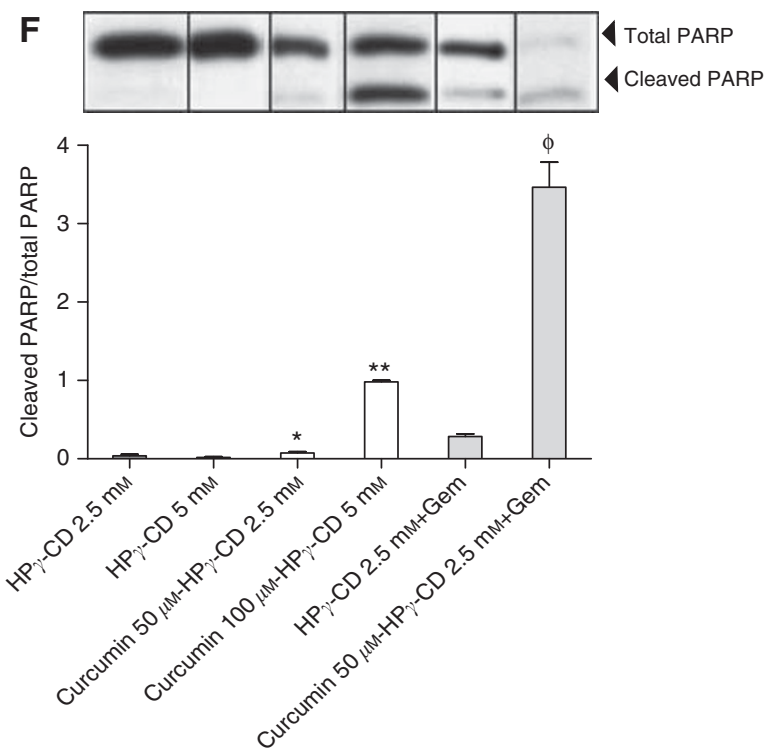

Figure 5 Induction of apoptosis by curcumin-CD. (A-E) Cells have been cultured in the presence of curcumin-CD alone or with gemcitabine for $24 \mathrm{~h}$, stained with annexin $\mathrm{V}$ and $\mathrm{Pl}$, and apoptosis rates (\%) have been evaluated by flow cytometry. Results are representative of three independent experiments. (F) PARP levels have been evaluated by western Blot. Lewis Lung Carcinoma cells have been cultured with various concentrations of curcumin-CD complexes alone or with gemcitabine for $24 \mathrm{~h}$. Results are expressed as ratio of cleaved PARP and total PARP levels \pm s.e.m. and are representative of two independent experiments performed in duplicates.

orally) and gemcitabine (administered i.p.) when compared with HP $\gamma$-CD- and NSC-treated groups. In vitro proliferation of LLC cells in culture medium enriched with curcumin-CD was reduced in a dose-dependent way showing that curcumin-CD complexes were able per se to influence tumour cell behaviour. However, in vivo, the use of curcumin and gemcitabine combination was the most effective experimental condition for reducing tumour cell proliferation suggesting that if curcumin alone was not sufficient in vivo to significantly decrease cell proliferation, its association with cytotoxic drugs would allow reaching maximal efficiency in lung cancer treatment schemes. Many hypotheses could explain this complementary effect of soluble curcumin on gemcitabine. Indeed, in vitro, the experimental system is simplified as only tumour cells are used while, in vivo, a whole organism, composed of different cell types, blood vessels and tumour stroma, has to be considered as well as a specific tumour microenvironment (Noel et al, 2008; Rocks et al, 2008b). One has to consider production of factors that might counteract direct effects of curcumin complexes on tumour cells. As curcumin has the potency to inhibit nuclear factor $\kappa \mathrm{B}$ (Aggarwal et al, 2005), and taking into account that many chemotherapeutic agents induce the activation of this transcription factor, a combined therapeutic strategy with curcumin could potentiate the effects of some chemotherapeutical agents by avoiding inappropriate activation of the NFKB pathway (Duarte et al, 2010). Several reports have already pointed out the importance of such an association of curcumin with a chemotherapeutic agent to sensitise cancer cells to chemotherapy in animal xenograft models (Aggarwal et al, 2005; Kunnumakkara et al, 2007).

Regulation of cell cycle through cyclins, cyclin-dependent kinases (CDK) as well as their inhibitors is crucial for normal cell growth. In G1 and G2 phases of cell cycle, checkpoints are monitoring the accuracy of DNA synthesis and cell mitosis, respectively (Paulovich et al, 1997), and deregulation of cell cycle regulatory elements has been described for many tumours (Vermeulen et al, 2003). It has been previously reported that treatment schemes with curcumin display the potency to reduce levels of cyclin D1 or B1 and block progression of tumour cells through G1 or G2 phases with accordingly reduced proliferation and enhanced apoptosis rates (Aggarwal et al, 2007; Srivastava et al, 2007; Saha et al, 2010). In vivo, curcumin has the ability to reduce tumour cell proliferation by modulating the expression of 
A

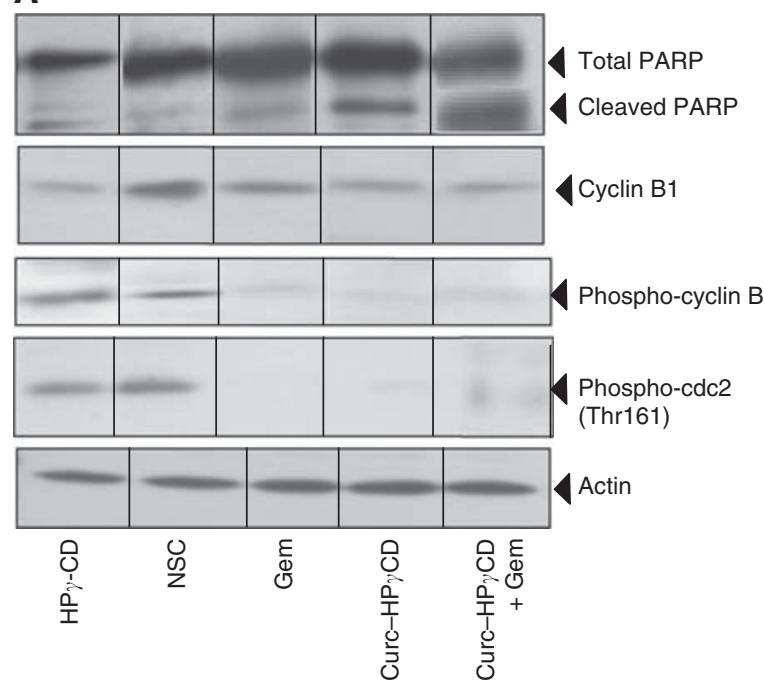

B

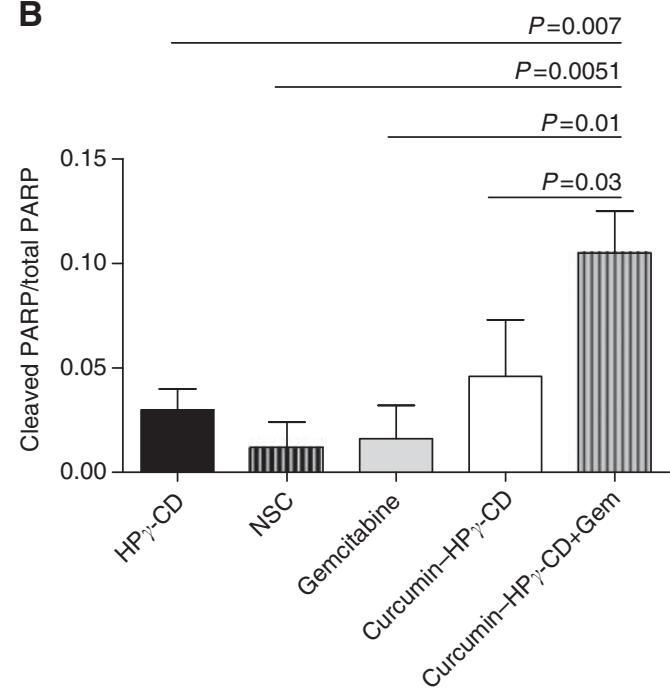

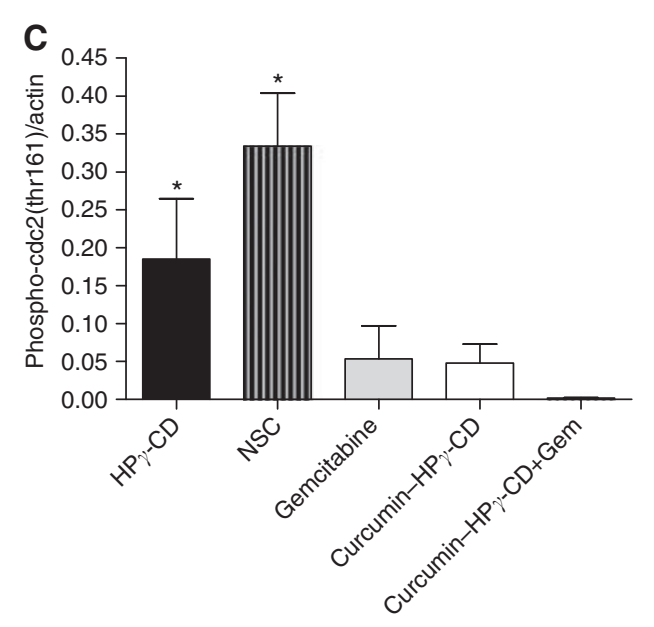

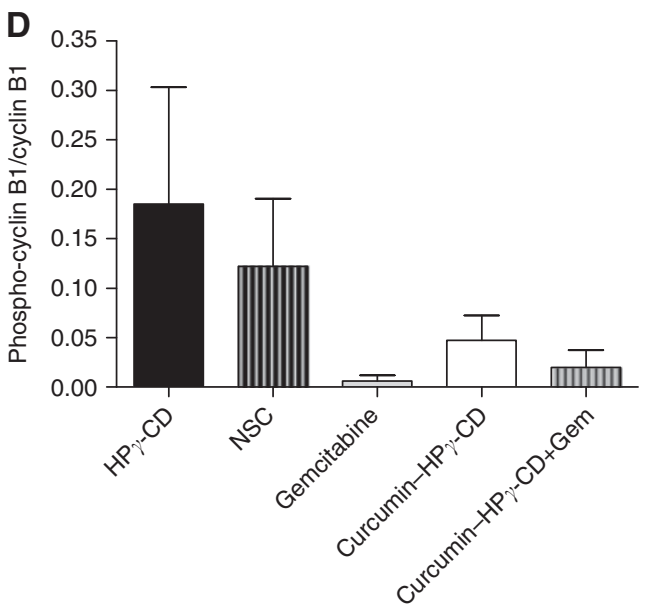

Figure 6 Curcumin-CD complexes affect the production of proteins related to apoptosis and cell cycle. (A) Western blot analyses have been performed to measure cleaved PARP, phospho-cyclin BI and phospho-cdc2 levels. Actin is shown as loading control. (B-D) Quantification was performed by densitometric scanning. Results are expressed as mean \pm s.e.m. and are representative of two independent experiments.

transcription factors or cyclins (Lin et al, 2007; Shankar et al, 2008; Wang et al, 2008). In the present study, we afford the demonstration that cell cycle was arrested in G2 phase in cells treated with curcumin-CD complexes. In order to better understand which regulatory proteins are affected by curcumin treatment, we investigated the production of cell cycle-related proteins and found levels of phosphorylated cyclin B1 to be downregulated in lungs of mice treated with curcumin-CD complexes or with the association of curcumin-CD complexes and gemcitabine. In addition, levels of threonine 161-phosphorylated cdc2 (cell division control protein 2 homologue or CDK1) were reduced in curcumin-CDs-treated lungs. These results are in accordance with reduced proliferation and enhanced apoptosis rates measured in tumours of mice and suggest that alteration of cell cycle phases is responsible for reduced lung tumour development observed in these animals.

Our study provides evidence pleading for a potential new treatment strategy in lung cancer. Recent studies have described the potential usefulness of curcumin as adjuvant therapy in different types of cancer such as pancreatic, bladder or colorectal cancer (Kunnumakkara et al, 2007; Patel and Majumdar, 2009; Tharakan et al, 2010). Given our current data based on effects of curcumin-CD complexes on lung cancer development, one can hypothesise that curcumin could provide complementary effects to conventional therapeutics in order to reach maximum treatment efficiency in patients. Its low intrinsic toxicity for non-diseased organs or cells implies that curcumin would specifically target lung tumour cells. However, association of curcumin with CD $\mathrm{HP} \gamma$ is mandatory to allow using a low-dose bioavailable curcumin that is preferable to reduce potential side effects.

\section{ACKNOWLEDGEMENTS}

This work was supported by grants from the Communauté française de Belgique (Actions de Recherches Concertées), the Fonds de la Recherche Scientifique Médicale, the Fonds National de la Recherche Scientifique (F.N.R.S., Belgium), the Fonds spéciaux de la Recherche (University of Liège), the Fondation Léon Fredericq (University of Liège), the D.G.T.R.E. from the " Région Wallonne ", the Fondation against Cancer, European Union Framework Programs FP7-HEALTH-2007 (Microenvimet $\mathrm{n}^{\circ}$ 201279), the Interuniversity Attraction Poles Programme Belgian Science Policy (Brussels, Belgium). N Rocks is a fellow of the Neoangio Programme (Région Wallonne, Belgium). We especially thank Christine Fink and Fabienne Perin for their excellent technical assistance. 


\section{REFERENCES}

Aggarwal BB, Banerjee S, Bharadwaj U, Sung B, Shishodia S, Sethi G (2007) Curcumin induces the degradation of cyclin $\mathrm{E}$ expression through ubiquitin-dependent pathway and up-regulates cyclin-dependent kinase inhibitors p21 and p27 in multiple human tumor cell lines. Biochem Pharmacol 73: 1024-1032

Aggarwal BB, Shishodia S, Takada Y, Banerjee S, Newman RA, Bueso-Ramos CE, Price JE (2005) Curcumin suppresses the paclitaxelinduced nuclear factor-kappaB pathway in breast cancer cells and inhibits lung metastasis of human breast cancer in nude mice. Clin Cancer Res 11: 7490-7498

American Cancer Society. Cancer Facts \& Figures 2010. American Cancer Society: Atlanta, 2010

Binder D, Hubner RH, Temmesfeld-Wollbruck B, Schlattmann P (2011) Pulmonary toxicity among cancer patients treated with a combination of docetaxel and gemcitabine: a meta-analysis of clinical trials. Cancer Chemother Pharmacol 68: 1575-1583

Chen HW, Lee JY, Huang JY, Wang CC, Chen WJ, Su SF, Huang CW, Ho CC, Chen JJ, Tsai MF, Yu SL, Yang PC (2008) Curcumin inhibits lung cancer cell invasion and metastasis through the tumor suppressor HLJ1. Cancer Res 68: 7428-7438

Duarte VM, Han E, Veena MS, Salvado A, Suh JD, Liang LJ, Faull KF, Srivatsan ES, Wang MB (2010) Curcumin enhances the effect of cisplatin in suppression of head and neck squamous cell carcinoma via inhibition of IKKbeta protein of the NFkappaB pathway. Mol Cancer Ther 9: 2665-2675

Evrard B, Bertholet P, Gueders M, Flament MP, Piel G, Delattre L, Gayot A, Leterme P, Foidart JM, Cataldo D (2004) Cyclodextrins as a potential carrier in drug nebulization. J Control Release 96: 403-410

Kanai M, Yoshimura K, Asada M, Imaizumi A, Suzuki C, Matsumoto S, Nishimura T, Mori Y, Masui T, Kawaguchi Y, Yanagihara K, Yazumi S, Chiba T, Guha S, Aggarwal BB (2011) A phase I/II study of gemcitabinebased chemotherapy plus curcumin for patients with gemcitabineresistant pancreatic cancer. Cancer Chemother Pharmacol 68: 157-164

Kunnumakkara AB, Anand P, Aggarwal BB (2008) Curcumin inhibits proliferation, invasion, angiogenesis and metastasis of different cancers through interaction with multiple cell signaling proteins. Cancer Lett 269: 199-225

Kunnumakkara AB, Guha S, Krishnan S, Diagaradjane P, Gelovani J, Aggarwal BB (2007) Curcumin potentiates antitumor activity of gemcitabine in an orthotopic model of pancreatic cancer through suppression of proliferation, angiogenesis, and inhibition of nuclear factor-kappaB-regulated gene products. Cancer Res 67: 3853-3861

Lin YG, Kunnumakkara AB, Nair A, Merritt WM, Han LY, Armaiz-Pena GN, Kamat AA, Spannuth WA, Gershenson DM, Lutgendorf SK, Aggarwal BB, Sood AK (2007) Curcumin inhibits tumor growth and angiogenesis in ovarian carcinoma by targeting the nuclear factorkappaB pathway. Clin Cancer Res 13: 3423-3430

Nasrallah H, Bar-Sela G, Haim N (2012) Fatal interstitial lung disease associated with gemcitabine and erlotinib therapy for lung cancer. Med Oncol 29: 212-214

Noel A, Jost M, Maquoi E (2008) Matrix metalloproteinases at cancer tumor-host interface. Semin Cell Dev Biol 19: 52-60

Patel BB, Majumdar AP (2009) Synergistic role of curcumin with current therapeutics in colorectal cancer: minireview. Nutr Cancer 61: 842-846
Paulovich AG, Toczyski DP, Hartwell LH (1997) When checkpoints fail. Cell 88: 315-321

Pawlik TM, Keyomarsi K (2004) Role of cell cycle in mediating sensitivity to radiotherapy. Int J Radiat Oncol Biol Phys 59: 928-942

Ravindran J, Prasad S, Aggarwal BB (2009) Curcumin and cancer cells: how many ways can curry kill tumor cells selectively? AAPS J 11: 495-510

Rocks N, Estrella C, Paulissen G, Quesada Calvo F, Gilles C, Gueders M, Crahay C, Foidart JM, Gosset P, Noel A, Cataldo D (2008a) The metalloproteinase ADAM-12 regulates bronchial epithelial cell proliferation and apoptosis. Cell Prolif 41: 988-1001

Rocks N, Paulissen G, Quesada-Calvo F, Munaut C, Gonzalez ML, Gueders M, Hacha J, Gilles C, Foidart JM, Noel A, Cataldo DD (2008b) ADAMTS-1 metalloproteinase promotes tumor development through the induction of a stromal reaction in vivo. Cancer Res 68: 9541-9550

Saha A, Kuzuhara T, Echigo N, Fujii A, Suganuma M, Fujiki H (2010) Apoptosis of human lung cancer cells by curcumin mediated through up-regulation of 'growth arrest and DNA damage inducible genes 45 and 153'. Biol Pharm Bull 33: 1291-1299

Shankar S, Ganapathy S, Chen Q, Srivastava RK (2008) Curcumin sensitizes TRAIL-resistant xenografts: molecular mechanisms of apoptosis, metastasis and angiogenesis. Mol Cancer 7: 16

Sreekanth CN, Bava SV, Sreekumar E, Anto RJ (2011) Molecular evidences for the chemosensitizing efficacy of liposomal curcumin in paclitaxel chemotherapy in mouse models of cervical cancer. Oncogene 30: 3139-3152

Srivastava RK, Chen Q, Siddiqui I, Sarva K, Shankar S (2007) Linkage of curcumin-induced cell cycle arrest and apoptosis by cyclin-dependent kinase inhibitor p21(/WAF1/CIP1). Cell Cycle 6: 2953-2961

Tharakan ST, Inamoto T, Sung B, Aggarwal BB, Kamat AM (2010) Curcumin potentiates the antitumor effects of gemcitabine in an orthotopic model of human bladder cancer through suppression of proliferative and angiogenic biomarkers. Biochem Pharmacol 79: 218-228

Vermeulen K, Van Bockstaele DR, Berneman ZN (2003) The cell cycle: a review of regulation, deregulation and therapeutic targets in cancer. Cell Prolif 36: 131-149

Wang D, Veena MS, Stevenson K, Tang C, Ho B, Suh JD, Duarte VM, Faull KF, Mehta K, Srivatsan ES, Wang MB (2008) Liposomeencapsulated curcumin suppresses growth of head and neck squamous cell carcinoma in vitro and in xenografts through the inhibition of nuclear factor kappaB by an AKT-independent pathway. Clin Cancer Res 14: 6228-6236

Yadav VR, Prasad S, Kannappan R, Ravindran J, Chaturvedi MM, Vaahtera L, Parkkinen J, Aggarwal BB (2010) Cyclodextrin-complexed curcumin exhibits anti-inflammatory and antiproliferative activities superior to those of curcumin through higher cellular uptake. Biochem Pharmacol 80: $1021-1032$

Yodkeeree S, Chaiwangyen W, Garbisa S, Limtrakul P (2009) Curcumin, demethoxycurcumin and bisdemethoxycurcumin differentially inhibit cancer cell invasion through the down-regulation of MMPs and uPA. J Nutr Biochem 20: 87-95

Zhongfa L, Chiu M, Wang J, Chen W, Yen W, Fan-Havard P, Yee LD, Chan KK (2012) Enhancement of curcumin oral absorption and pharmacokinetics of curcuminoids and curcumin metabolites in mice. Cancer Chemother Pharmacol 69: 679-689

This work is published under the standard license to publish agreement. After 12 months the work will become freely available and the license terms will switch to a Creative Commons Attribution-NonCommercial-Share Alike 3.0 Unported License. 